\title{
AIR-BORNE DUST CONDITIONS IN BRITISH WARTIME FLAX SCUTCHING FACTORIES
}

\author{
BY \\ KENNETH L. GOODALL and P. J. HARDWICK \\ From the Factory Department, Ministry of Labour and National Service, London, and the \\ Department of the Government Chemist, Government Laboratory, London
}

(RECEIVED FOR PUBLICATION SEPTEMBER 7, 1950)

In Great Britain (excluding Northern Ireland) the acreage under flax had declined to 3 acres in 1931, but it had risen to 4,500 acres by 1939 . During the war when supplies were cut off from Europe the acreage of home-grown flax rapidly expanded, and by 1944 was 74,000 acres. This was required to meet the urgent need for such materials as parachute harness, ships' canvas, and hose pipes. As this was virtually a new industry, factories had to be created to deal with the home-grown crop. There were many initial troubles as there were few people in Britain with much experience of flax processing, and the crops, being new to farmers, were at first of very variable quality. The Select Committee on National Expenditure (1943) took evidence on the design of the factories and plant and on the efficiency of the dust extraction arrangements, and received many complaints which appeared to be justified. An ad hoc Committee on Dust Conditions in Flax Factories under the chairmanship of Major G. O. Searle, O.B.E., Superintendent of H.M. Norfolk Flax Establishment, was set up in 1943 to consider the existing system of dust extraction in the 17 flax factories and to indicate the modifications and improvements necessary in order that the standards of the Factories Acts might be met.

For this Committee we undertook the series of investigations of air-borne dust conditions in flax scutching factories which, we believe, are the first to be recorded.

\section{The Flax Dust Health Hazard}

Flax was cultivated some 6,000 years ago in ancient Egypt, where cloth made from it was used for wrapping mummies, and it is mentioned in the description in Exodus of the plagues of Egypt. The first mention of a health hazard appears to be by Ramazzini (1705) who, from personal observation in the textile trades, records that out of hemp and

D flax there flies "a foul mischievous powder, that, entering the lungs by the mouth and throat, causes continual coughs, and gradually makes way for asthma".

The dust problems associated with the conversion of flax into linen probably only became acute during the industrial revolution, and a number of authors write about the primitive conditions in the industry during that period. Thackrah (1832) gives a particularly full account of such conditions in flax factories in the Leeds area, in which many young women and children of 7 to 15 years of age were employed for a $13 \frac{1}{2}$-hour day in a very dusty and humid environment. Their inevitable ill health took the form of indigestion and gastritis, morning vomiting, chronic bronchitis and harsh coughing, emphysema, premature ageing and death, and a hastening of any consumptive tendencies. Very few employees survived 30 years' work in the hackling, and similarly dusty, preparatory processes.

Greenhow (1860) records how he found 23 out of 27 hacklers at a Pateley Bridge flax mill habitually asthmatical, the older men (rarely over 60 ) being short-breathed and round-shouldered, with emaciated frames, prominent eyes, and a laborious wheezing respiration. He comments on the irritation produced in the nasal and bronchial passages of workers by the flax dust which causes sneezing and a sense of oppression in the chest, especially on first entering the mills, and subsequently at the beginning of the week. In time the operatives become more or less inured to these effects, but as life advances their resistance diminishes and they suffer from dyspnoea, chronic bronchitis, and sometimes from emphysema. Similar views were held by Purdon (1873), who had extensive medical experience of conditions in flax spinning mills in the Belfast area. 
Arlidge (1892) considered that flax dust was more pernicious to the respiratory organs than any other textile dusts except jute and hemp, and that the early or preparatory processes in the scutch-mills and spinning mills were easily the worst for producing dust. Attempts to suppress the dust, which is described as " a very fine, soft and palpable powder, far more granular than fibrous in constitution and containing $13 \%$ of silica", were by humidification and better ventilation of the shops, machine enclosure and the use of some localized exhaust. The inhalation of flax dust in the first few days of employment in hot, humid and dusty flax spinning rooms caused severe " mill fever", ushered in by chills, nausea and vomiting, quickly followed by headache, thirst and heat of the skin. After two to eight days the fever disappeared leaving the workers weak and languid. Prolonged inhalation of flax dust led to bouts of coughing and to dyspnoea which, in advanced cases, were distressing and paroxysmal in character, sometimes ending with vomiting or expectoration of blood. He concludes :

"Chronicity is the characteristic of the chest disease, which sooner or later declares itself in the haggard wasted features, in general emaciation, in the rounded shoulders, and in the tottering gait of its victims."

Osborn (1894) reports the experiences of 14 medical observers, five of whom exonerated flax dust of the then current charge that it predisposed to phthisis. He agrees with them and with Greenhow that bronchial catarrh, accompanied by asthma, is frequently caused by breathing the dusty atmosphere of flax mills, and that the flax hacklers die young and suffer from chronic disease of the lungs.

Glibert (1902), a Belgian Medical Inspector of Factories examined 12,275 workers in the Belgian flax spinning industry but only in processes subsequent to scutching,* mainly hackling, carding, spreading and drawing on fly or roving frames, spinning, winding, drying and packing, the first two being the dustiest and worst operations from the health point of view. Glibert considered that the abundance of air-borne mineral dust which he observed in the spinning mill atmosphere was because the stem of the flax plant was rich in silica, and that the injuriousness of flax dust was due to this. He added that flax dust, when inhaled, caused irritation of the upper respiratory passages leading to inflammatory lesions, bronchitis, asthma and pneumonia, and that it acted through its physical and chemical properties and its ability to carry pathogenic micro-organisms.

\footnotetext{
* Technical terms involved in processing flax are briefly explained in the next section of the paper.
}

Collis (1915), from personal enquiry, was convinced that asthma was still prevalent amongst operatives in the early stages of flax processing though declining in severity with improvements in methods of dust removal.

Bargeron (1930), of the French Factory Inspectorate, refers to the abundant and harmful dust created by the operations of breaking and scutching flax, to the enormous numbers of spores generated in the material at this stage of its processing, and to the need for capturing the dust locally at the point of origin, preferably by downward exhaust ventilation. Carding and hackling are again mentioned as exceptionally dusty and unhealthy processes, and Verhaegue of Lille is quoted as having examined 41 hand hacklers of whom 28 were victims of chronic affections of the respiratory tract, especially coughing. Mill fever lasting three or four days is stated to be common amongst linen workers on first employment, and Bargeron is inclined to attribute the fever to a mould. The inhalation of flax dust, in his experience, also led to asthmatic attacks, accompanied by spasms of the bronchial muscles and swelling of the mucous membrane.

Thiry (1941) recognized the important part played by the presence in the air of flax spinning mills of large numbers of spores, moulds, and staphylococci and considered that these agencies, much more than the dust itself, were the cause of ill health in flax workers. Among workers with at least 10 years' exposure, Thiry noted a high incidence of chest disease, but no case of pure silicosis, despite the reputed presence of silica in flax dust. He examined 123 such flax workers in modern, spacious and well ventilated Belgian factories and found that $41 \%$ had evidence of chest disease, as against $88 \%$ in a similar survey of Belgian cotton workers, a difference in favour of flax which is recognized by the Ghent workers who say le lin digère mieux.

\section{The Modern Flax Scutching Process}

There are fascinating descriptions of the structure, cultivation, harvesting, grading, and factory processing of flax and of the engineering equipment of flax scutching mills in papers by Turner (1949), Barltrop (1942), Oldham (1948), and Grainger (1949); and the Ministry of Supply has published a glossary of technical terms (1944).

A brief description of the flax scutching processes is given in the Report of the Select Committee (1943), as follows :-

" First, the crop has to be pulled, not cut, and then de-seeded. Until recent years the next step was invariably "retting", which consists of steeping the straw in water in order to rot or ret the woody matter 
so that it may more readily be separated from the fibre. This may be done in one of three ways : dewretting, which is merely to lay the straw out in the fields and thus expose it to the action of dew or rain ; dam retting, which entails soaking it for some days in the water of a stream, pond or lake ; and tank retting (which may be aerobic or anaerobic) whereby the straw is soaked in a tank of warm water. The next stage (after drying the straw by stacking in the fields, or artificially) is the actual separation of the wood from the fibre, which today is done in a machine called a turbine scutcher. This machine performs two operations, the first being to break the woody constituents of the straw into short pieces by passing the straw between fluted rollers under pressure; the second being to dislodge this wood or 'shive' from the fibre by the flaying action of rotating beater blades. The resulting product is 'scutched flax' or 'long fibre' but a byproduct is 'scutching rug.', which consists of the short, partly scutched straw thrown out with the shive during the processing. This scutching rug can be rescutched to produce 'tow'. The scutched flax and tow then go to the spinners to be spun into yarn. There is, however, a new processing method now in use by which the retting is dispensed with and the straw is fed direct from the de-seeding apparatus to the scutching machines. This is known as "green scutching' and produces 'green' or 'natural' fibre and tow. The weight of scutched flax produced, either retted or un-retted, as a result of all these processes is only a small percentage (some 8 to $10 \%$ of the dry straw with bolls) of the original crop weight."

For reasons connected with training operatives, retting effluent and drying problems, and the need to conserve flax seed, green scutching had to be adopted during the war. It was discontinued in favour of the scutching of retted straw as soon as it was possible to do so, as retted fibre is superior in quality to green.

Of the 17 war time flax scutching factories not all were of the standard design built specially for the purpose and illustrated in Fig. 1. In the standard factories, of which Devizes (Wiltshire), Fordham
(Cambridgeshire), Howden (Yorkshire), and Pluckley (Kent) were typical and chosen for our dust measurements, the dust extraction systems were all of much the same type, and each consisted of three sections discharging to bag filters outside the scutching room. One section, connected to the de-seeding machines, extracted dust upwards from hoods over the machines by means of a centrifugal fan. The second was over the turbine scutchers, drawing dust upwards by means of an axial flow fan. The third section was the shive extraction exhaust system from the bottom of the low speed shakers and tow rollers, the dust being extracted through a cyclone into the bag filters.

Except at Pluckley, where heating was by unit heaters, a plenum system supplied fresh air from outside.

At Blairgowrie (Perthshire), one of the older non-standard factories where we made dust measurements, the whole scutching room had been changed over to a downwards extraction system of ventilation by removing the turbine hoods completely. The conveyors carrying rug tow away from the turbine and also the low speed shakers were encased and put under slight suction; and the shive extraction exhaust served for dust extraction as well. There was no plenum ventilation system.

The arrangement of the scutching room ventilation at West Newton, also one of the older non-standard factories, is referred to later in the paper.

\section{Sources and Effects of Dust in Flax Scutching Factories}

In flax factories there are four main sources of dust ; the de-seeding process, the scutching process, the tow machinery, and the general handling of

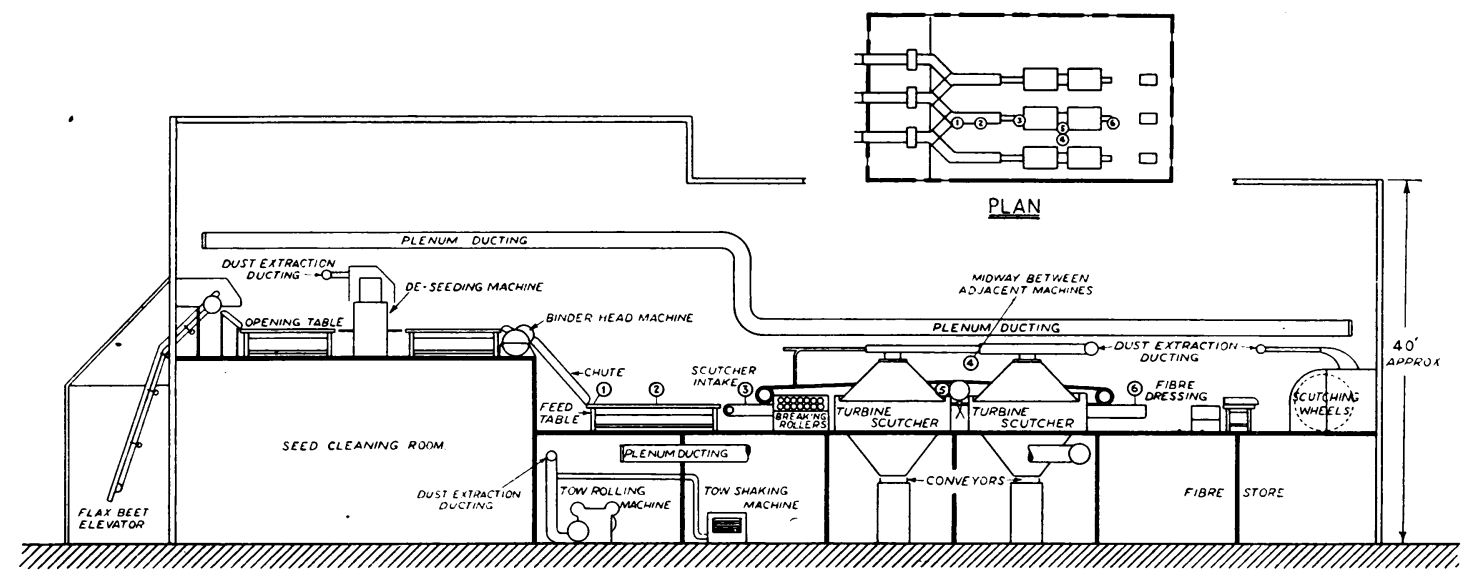

FIG. 1.-Plan of standard flax scutching factory. 
the straw. In the majority of factories the first two processes are carried out in the same room-the scutching room-where also the maximum handling of the straw takes place and the greatest number of operatives is employed. The amount of dust seen at preliminary visits to a number of typical flax scutching factories varied considerably. Much depended on the type of flax being scutched, and in the early stages of the scheme the flax crops were of very variable quality and dust content. The old straw remaining from a previous season's crop was particularly dusty. Some factories were using green flax, others aerobically or anaerobically retted flax. From some of the scutching turbine machines dust leaked into the workrooms. Some factories had to operate the night shifts under complete black-out conditions with all the attendant ventilation difficulties, which were aggravated in a few of the non-standard factories by the low roofs of the scutching rooms. Finally, a high general standard of cleanliness in the workrooms was not maintained owing to shortages of staff and materials.

Although the workers in the scutching rooms were in good general health some were affected by the dust.

The workers found the dust from retted flax much more irritating than that from green flax, and considered aerobically retted flax worst of all. Both types, but especially the latter, caused workers to complain of headaches, of a temporary feeling of suffocation and sickness, and of severe pain and soreness in the throat and upper part of the chest which persisted over a period of one or two days and caused bouts of coughing. Such troubles were most marked at the beginning of the scutching season and on resuming work after the week-end breaks. No worker had to be permanently removed from the scutching rooms for health reasons, and sickness absence was low compared with that in Royal Ordnance factories. Some workers appeared more sensitive to flax dust than others. The factory medical officers reported complaints of headaches and nose bleeding which were considered to be due to irritation and swelling of the mucous membranes of the upper respiratory passages ; of a feeling of constriction and tightness in the throat and chest; and of a rash on the forearms.

The bacterial and fungal contents of scutching room dust were investigated for the Committee by other workers and will not be discussed here. Further information on the bacteria active in flax retting in England and on the relationship of fibre quality to bacterial flora in flax retting will be found in papers by Allen (1946) and Lanigan (1950) respectively.

\section{Measurements of Dust}

To improve dust conditions, and, if possible, to fix desirable levels of air-borne dust concentrations, it was first necessary to obtain data on air-borne dust in as many scutching factories as possible under different conditions.

Six standard sampling positions, all at breathing level, were chosen for tests in scutching rooms at points where employees worked or where the maximum amount of dust was likely to be liberated. They were (Fig. 1) :-

Position 1, at the end of the turbine scutcher feed table farthest from the machine, facing the centre of the table at a point where the flax beets (bundles) were being opened up by hand ; position 2 , midway along the feed table, facing workers; position 3 , at the intake to the scutching machine, facing the centre of the table; position 4, between the turbine casings of adjacent scutching machines, facing the fibre dressing end, to assess the general atmosphere of the scutching room; position 5, near the centre of the turbine scutcher, at the change-over point between the hoods, facing the feed table end ; and position 6 , at the fibre dressing end of the machine, facing workers.

Gravimetric dust estimations were mostly made at all six sampling points simultaneously and dust counts, when taken, were made concurrently at positions 1 and 4.

\section{Dust Sampling Methods}

Long period dust sampling methods were chosen to determine average dust concentrations over a representative period during a shift after the scutching machines had been working for at least $\mathbf{3 0}$ minutes to an hour and steady running conditions had been reached.

Visually, air-borne dust conditions did not appear to vary much throughout a shift. This was confirmed by the repeated series of dust estimations made during a shift at the Fordham factory, which, as will be seen from Table 4, showed excellent agreement. In consequence only one dust estimation was made at each sampling position during a shift, and an hour's sampling was found sufficient to give an amount of dust which was measureable with reasonable accuracy.

For the earlier surveys we ran simultaneously a thermal precipitator and a gravimetric sampler. The unincinerated thermal precipitator deposits were counted and sized under light field conditions using a $2 \mathrm{~mm}$. oil immersion apochromatic objective, N.A.1.34, a condenser of similar N.A., and a $\times 20$ compensating eyepiece, resolution being obtained down to approximately $0 \cdot 2 \mu$. 
The particle-number and gravimetric concentrations of typical flax scutching dust clouds were found to be roughly correlated (correlation coefficient $=+0.63$ ). The gravimetric method of sampling was chosen for the later surveys. Sintered glass filters were used and since, as far as we are aware, this method for air-borne dust sampling has not previously been described, a few details of the apparatus and measurements of its efficiency against finely particulate dust clouds are given in the Appendix.

The advantages of filtration apparatus embodying sintered glass filtering discs when used for straightforward filtration of laboratory precipitates have been dealt with by Peel (1947), whose paper also gives useful technical information concerning the different porosities available and methods of cleaning filters for re-use. Our own experience, subsequently extended by the use of these filters in cotton cardrooms, indicates that for gravimetric sampling of air-borne industrial dusts they are most satisfactory. The gravimetric results are given to the nearest milligram per cubic metre. Weighings were made to the nearest $0.1 \mathrm{mg}$., which was the limit of sensitivity of the balance. Preliminary replicate weighings of control filters had shown good agreement within this sensitivity.

\section{First Series of Dust Measurements}

Devizes and Blairgowrie Flax Factories.-This series of measurements was made to assess, under comparable conditions, the relative effectiveness of the up-draught (Devizes) and down-draught (Blairgowrie) systems of dust extraction on the scutching machines, the effectiveness of the overhead fabric duct-plenum system of ventilation at Devizes, and to obtain preliminary information as to the amount of air-borne dust which was present and could be tolerated in the factories.

Tests at both factories were carried out under black-out conditions (to obtain the worst conditions possible) using material from the same batch of dusty, tank-retted straw. As this straw contained no seeds the de-seeding machines were not in use at either factory during the tests.

At Devizes, a standard factory which had a specially good record for cleanliness, tests were made separately along one side of the centre of three scutching machines over periods of about three-quarters of an hour, first with and then without the plenum system in operation, after the scutchers had run for about two hours. With the plenum system in action the general condition of the atmosphere seemed tolerable except at the feeding tables. Without it, conditions deteriorated rapidly.
At Blairgowrie, a non-standard factory, the plant arrangement was somewhat similar to that at Devizes. Tests were made for an hour after the scutching machines had been running normally for about three hours. Before this the factory had not been in normal production and the scutching machinery and plant had received a seasonal cleaning. The factory was thus probably much cleaner than it would be after a period of normal running. Also there was at this factory a strong draught of fresh air passing through the scutching room from flax-beet conveyor-belt openings at the feed end of the room. On the other hand, the general ventilation extraction fan in the roof of the scutching room was not running during the tests. The general condition of the atmosphere appeared visually to be very satisfactory. Compared with Devizes very little dust seemed to originate at the feed tables where the flax beets were opened up, the straw appearing to be much less dusty than that used at Devizes. The results of the tests are recorded in Tables 1 and 2.

West Newton and Fordham Flax Factories.-It was decided to extend this series of measurements to two further factories, West Newton and Fordham, where somewhat different conditions obtained. West Newton was a non-standard factory, where the scutching room was rather crowded and contained five machines fitted with upward dust extraction and working on both retted and green straw. The de-seeding machines were in a separate room. The scutching room, $70 \mathrm{ft}$. wide, was only about $10 \mathrm{ft}$. wider than that at Devizes, which like all the standard factories had only three machines, and its height was only $10 \mathrm{ft}$., as compared with $15 \mathrm{ft}$. at Devizes, while the roof had a lower pitch. A plenum system was installed giving, normally, a larger number of air changes as compared with systems installed at standard factories so that, on balance, ventilation conditions per machine were designed to be much the same in the two types of factory.

The factory had been running normal shifts before the tests were made but some special cleaning up of the scutching room had been done. The day-time tests were made with four of the five scutching machines in operation using retted straw, dust samples being taken at standard positions along one side of one of the inner machines over a period of an hour after the machines had been running continuously for about an hour. The machine not working was on the outside and the plenum system was operating at half capacity. The humidity was high and a strong wind produced a noticeable current of fresh air from the flax beet 
TABLE 1

GRAVIMETRIC AND DUST COUNT ESTIMATIONS AT DEVIZES FLAX FACTORY UNDER BLACK-OUT CONDITIONS

\begin{tabular}{|c|c|c|c|c|c|c|c|c|c|c|c|c|c|}
\hline \multirow[b]{2}{*}{$\begin{array}{l}\text { Sampling } \\
\text { Position }\end{array}$} & \multicolumn{2}{|r|}{ • } & \multicolumn{4}{|c|}{ Plenum On } & \multicolumn{7}{|c|}{ Plenum Off } \\
\hline & $\begin{array}{c}\text { Total } \\
\text { Dust } \\
\left(\mathrm{mg} . / \mathrm{m}^{3}\right)\end{array}$ & $\begin{array}{c}\text { Mineral } \\
\text { Dust } \\
\text { and } \\
\text { Organic } \\
\text { Ash } \\
\left(\mathrm{mg} . / \mathrm{m}^{3}\right)\end{array}$ & \begin{tabular}{|} 
Dust \\
Concen- \\
tration \\
(particles \\
per \\
c.cm.)
\end{tabular} & Size & Distribution & & $\underset{\left(\mathrm{mg} \cdot / \mathrm{m}^{3}\right)}{\text { Total }}$ & $\begin{array}{c}\text { Mineral } \\
\text { Dust } \\
\text { and } \\
\text { Organic } \\
\text { Ash } \\
\left(\mathrm{mg} . / \mathrm{m}^{3}\right)\end{array}$ & $\begin{array}{c}\text { Dust } \\
\text { Concen- } \\
\text { tration } \\
\text { (particles } \\
\text { per } \\
\text { c.cm.) }\end{array}$ & $\mathbf{S i}$ & ize Dist & tribution & \\
\hline 1. Feed table $\quad$. & 67 & 21 & 190 & $\begin{array}{l}\text { Median size } \\
99 \% \text { over } \\
92.5 \% \quad ", \\
81 \% \quad, " \\
61 \% \quad, " \\
18 \% \quad \text { ", }\end{array}$ & $\begin{array}{l}2 \cdot 6 \mu \\
0 \cdot 2 \mu(1 \% \\
0 \cdot 5 \mu 7.5 \% \\
1 \mu \quad(19 \% \\
2 \mu \quad 39 \% \\
5 \mu \quad(82 \% \\
\end{array}$ & 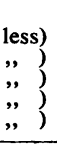 & 39 & 12 & 190 & $\begin{array}{l}\text { Media } \\
97 \% \\
87 \% \\
74 \% \\
52 \% \\
14 \% \\
\end{array}$ & 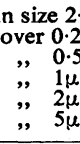 & $\begin{array}{l}-1 \mu \\
2 \mu(3 \% \\
5 \mu(13 \% \\
\quad 26 \% \\
\quad 148 \% \\
\quad 186 \% \\
\end{array}$ & $\begin{array}{l}\text { less) } \\
\text { ") } \\
\text { ", } \\
,, \text { ) }\end{array}$ \\
\hline 3. Scutcher intake.. & 67 & 21 & - & & - & & 32 & 11 & - & & - & - & \\
\hline $\begin{array}{l}\text { 4. General } \\
\text { atmosphere }\end{array}$ & 4 & 2 & 42 & $\begin{array}{l}\text { Median size } \\
95 \cdot 5 \% \text { over } \\
83 \cdot 5 \% \quad, " \\
67 \% \quad, " \\
46 \% \quad, " \\
17 \% \quad, "\end{array}$ & $\begin{array}{l}1 \cdot 75 \mu \\
0.2 \mu(4.5 \% \\
0.5 \mu(16.5 \% \\
1 \mu \quad(33 \% \\
2 \mu,(54 \% \\
5 \mu \quad(83 \%\end{array}$ & $\begin{array}{l}\text { ess }) \\
\text {," } \\
\text {," } \\
\text {," }\end{array}$ & 25 & 11 & 233 & $\begin{array}{l}\text { Media } \\
95 \cdot 5 \% \\
86 \% \\
73 \% \\
51 \% \\
18 \%\end{array}$ & $\begin{array}{c}\text { n size } 2 \\
\text { over } 0 \cdot \\
\Rightarrow \quad 0 \cdot 5 \\
\Rightarrow \quad 1 \mu \\
\Rightarrow \quad 2 \mu \\
\Rightarrow \quad 5 \mu\end{array}$ & $\begin{array}{l}.05 \mu \\
2 \mu .(4.5 \%) \\
5 \mu(14 \% \\
(27 \% \\
(49 \% \\
(82 \%\end{array}$ & $\begin{array}{l}\text { less) } \\
\text {," ) } \\
,, \text { ) }\end{array}$ \\
\hline $\begin{array}{l}\text { 5. Centre of } \\
\text { scutcher }\end{array}$ & 16 & 5 & - & & - & & 46 & 12 & - & & - & - & \\
\hline 6. Fibre dressing .. & 14 & 3 & - & & 一 & & 28 & 11 & - & & 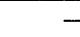 & - & \\
\hline Overall averages $\ldots$ & 34 & 10 & 一 & & - & & 34 & 11 & - & & & - & \\
\hline Overall ranges & $4-67$ & $2-21$ & - & & - & & $25-46$ & $11-12$ & 一 & & - & - & \\
\hline
\end{tabular}

The straw used during these tests was poor quality, dusty, tank-retted straw, with a moisture content of $16.5 \%$, and the feed weight/ machine/hr. was $580 \mathrm{lb}$.

TABLE 2

GRAVIMETRIC AND DÚST COUNT ESTIMATIONS AT BLAIRGOWRIE FLAX FACTORY UNDER BLACK-OUT CONDITIONS

\begin{tabular}{|c|c|c|c|c|c|}
\hline \multirow{2}{*}{\multicolumn{2}{|c|}{ Sampling Position }} & \multicolumn{4}{|c|}{ No Plenum } \\
\hline & & $\begin{array}{l}\text { Total Dust } \\
\left(\mathrm{mg} \cdot / \mathrm{m}^{3}\right)\end{array}$ & $\begin{array}{c}\text { Mineral } \\
\text { Dust and } \\
\text { Organic Ash } \\
\left(\mathrm{mg} . / \mathrm{m}^{3}\right)\end{array}$ & $\begin{array}{c}\text { Dust } \\
\text { Concentration } \\
\text { (particles } \\
\text { per c.cm.) }\end{array}$ & Size Distribution \\
\hline 1. Feed table $\quad \ldots$ & $\cdots$ & 5 & 3 & 155 & $\begin{array}{l}\text { Median Size } 1.6 \mu \\
97.5 \% \text { over } 0.2 \mu(2.5 \% \text { less }) \\
86 \% \quad, \quad 0.5 \mu(14 \% \quad, \quad) \\
68 \% \quad, \quad 1 \mu(32 \% \quad,) \\
40 \% \quad, \quad 2 \mu(60 \% \quad,) \\
5 \% \quad, \quad 5 \mu(95 \% \quad,)\end{array}$ \\
\hline 3. Scutcher intake .. & . & 28 & 11 & - & - \\
\hline 4. General atmosphere & . & 5 & 2 & 113 & $\begin{array}{l}\text { Median Size } 1.45 \mu \\
97.5 \% \text { over } 0 \cdot 2 \mu(2 \cdot 5 \% \text { less }) \\
83 \% \quad, \quad 0 \cdot 5 \mu(17 \% \quad,) \\
63 \% \quad, \quad 1 \mu(37 \% \quad,) \\
37 \% \quad, \quad 2 \mu(63 \% \quad,) \\
9 \% \quad, \quad 5 \mu(91 \% \quad,)\end{array}$ \\
\hline 5. Centre of scutcher & . & 7 & 3 & 一 & - \\
\hline 6. Fibre dressing $\ldots$ & $\cdots$ & 14 & 3 & - & - \\
\hline Overall averages & . & 12 & 4 & - & - \\
\hline Overall ranges & . & $5-28$ & $2-11$ & - & - \\
\hline
\end{tabular}

The straw used during the tests was poor quality, dusty, tank-retted straw, with a moisture content of $17.2 \%$, and feed weight/machine/ hr. of $624 \mathrm{lb}$. 
elevator openings towards the fibre dressing end of the room. Conditions were thus unfavourable to high concentrations of dust, and visually the general atmosphere seemed reasonably clean. The tests under black-out conditions were also made with the same four machines running but using green flax straw. The tests were made at similar positions over a period of an hour after the machines had been running for an hour. The plenum system of ventilation was not working on account of the low outside temperature and temporary disuse of the heating system. The results are given in Table 3 .

Fordham was a non-standard factory though not differing markedly from the standard type. It operated a two-shift system with three upwardexhausted scutching machines using green straw fed by three de-seeding machines also in action in the same room. Dust determinations were made under normal night time black-out conditions with the standard fabric plenum system in operation. The tests were begun after the night shift had been operating the scutching machines for half an hour and covered a period of three-quarters of an hour. After an interval of a quarter of an hour a repeat series of tests was made in the same standard sampling positions to check the consistency of the results. As will be seen from Table 4 very satisfactory agreement was obtained. This was the first factory tested at which the de-seeding machines in the scutching room were also in action.

\section{Discussion on First Series of Tests}

A strict comparison of the results obtained in the scutching rooms of the four factories (Tables 1-4) is not warranted owing to inevitable variations in the type of flax straw, the use of de-seeding machines, variations in humidity and other atmospheric conditions during the tests, structural differences in the scutching rooms, and minor variations in the lay-out and capacity of the dust extraction plants and plenum systems, but the following general observations can be made :-

Using the same type of dusty retted straw, the average dust content of the air at Devizes was greater than at Blairgowrie.

Except at the scutcher feed tables and intakes the dust conditions were much better at the Devizes factory when the plenum system was in operation.

At West Newton the day-time dust conditions were reasonably good and at none of the test points was there a high concentration. Under black-out conditions, however, with the plenum off, there was a considerable increase in atmospheric dustiness, with a particularly marked deterioration in conditions near the scutcher intake.
At Fordham the atmosphere under black-out conditions was generally the worst of those measured in this series of tests. Repeat tests confirmed this finding.

The efficiency of the dust extraction plants and the plenum systems did not appear to have much effect on the dust concentration at the feeding tables. The figures given for test positions 1 and 3 at the feed tables and scutcher turbine intakes did not indicate the relative effectiveness of the main scutcher dust extraction plants, as at none of the factories at the time of the tests had provision been made for localized exhaust control of the dust at these points. It seemed likely therefore, since the samples were taken immediately above the tables, that the results obtained at these positions indicated roughly the relative dustiness of the flax processed at the various factories. On this basis the results would indicate that the flax processed during the tests varied widely in dustiness.

The percentage of mineral matter and organic ash in the air-borne dust varied with the factory and the point of sampling, but in general was highest at the intake to the scutchers and lowest at the fibre dressing end of the machines.

While the thermal precipitator dust count results were not very high at any of the factories and fell within a range of 42-283 particles per c.cm., the dust clouds were considerably coarser than those normally met with in the working atmospheres of other dusty factories such as potteries, foundries or cotton mills. The median particle sizes ranged around $2 \mu$, there being between five and $18 \%$ of the particles over $5 \mu$ in diameter, though very few indeed of these were larger than $20 \mu$ and only one was recorded as large as $100 \mu$. Nevertheless between 85 and $95 \%$, by number of particles constituting the dust clouds, were of a size capable of entering the lungs. In the range under $50 \mu$ high power microscope examination of thermal precipitator samples, of which Fig. 2 is a typical example, showed that for both green and retted flax dust less than $1 \%$ by number of the air-borne particles were of a fibrous nature. This suggests that the dust clouds formed in the scutching rooms were derived almost wholly from the cortex and woody matter of the flax straw.

A rough correlation between gravimetric and thermal precipitator measurements was observed. For this reason, and on account of the great saving of time involved, it was decided in subsequent tests to use the gravimetric method of sampling only.

On reviewing the results as a whole in relation to visual appraisal of the working atmospheres which had been tested and to the health of the workers already described, the Committee for which we made our investigations decided to accept dust concen- 
TABLE 3

GRAVIMETRIC AND DUST COUNT ESTIMATIONS AT WEST NEWTON FLAX FACTORY

\begin{tabular}{|c|c|c|c|c|c|c|c|c|c|c|c|}
\hline \multirow[b]{2}{*}{$\begin{array}{l}\text { Sampling } \\
\text { Position }\end{array}$} & \multicolumn{6}{|c|}{$\begin{array}{l}\text { Plenum On } \\
\text { (Daytime) }\end{array}$} & \multicolumn{5}{|c|}{$\begin{array}{l}\text { Plenum Off } \\
\text { (Black-out) }\end{array}$} \\
\hline & $\begin{array}{c}\text { Total } \\
\text { Dust } \\
\left(\mathrm{mg} \cdot / \mathrm{m}^{3}\right)\end{array}$ & $\mid \begin{array}{c}\text { Mineral } \\
\text { Dust } \\
\text { and } \\
\text { Organic } \\
\text { Ash } \\
\left(\mathrm{mg} . / \mathrm{m}^{3}\right)\end{array}$ & \begin{tabular}{|c|} 
Dust \\
Concen- \\
tration \\
(particles \\
per \\
c.cm.)
\end{tabular} & Size I & Distribution & & $\underset{\text { Total }}{\text { Dust }}$ & $\left|\begin{array}{c}\text { Mineral } \\
\text { Dust } \\
\text { and } \\
\text { Organic } \\
\text { Ash } \\
\left(\mathrm{mg} . / \mathrm{m}^{3}\right)\end{array}\right|$ & \begin{tabular}{|c|} 
Dust \\
Concen- \\
tration \\
(particles \\
per \\
c.cm.)
\end{tabular} & Size Distribution & \\
\hline 1. Feed table & 7 & 2 & 57 & $\begin{array}{l}\text { Median size } \\
100 \% \text { over } \\
97.5 \% \%, \\
70 \% \%, \\
40 \% \%, " \\
11 \%, ",\end{array}$ & $\begin{array}{l}1.5 \mu \\
0 \cdot 2 \mu(-\%) \\
0 \cdot 5 \mu(2.5 \% \\
1 \mu \quad(30 \% \\
2 \mu \quad(60 \% \\
5 \mu \quad(89 \%\end{array}$ & $\begin{array}{l}\text { less) } \\
, ",) \\
, ",)\end{array}$ & 18 & 5 & 135 & $\begin{array}{l}\text { Median size } 1 \cdot 7 \mu \\
100 \% \text { over } 0 \cdot 2 \mu(-\%) \\
96 \% \\
73 \%\end{array}$ & $\begin{array}{l}\text { less) } \\
\text {,") } \\
\text {,") } \\
\text {, ) }\end{array}$ \\
\hline 3. Scutcher intake.. & 21 & 7 & - & & - & & 113 & 60 & - & - & \\
\hline $\begin{array}{l}\text { 4. General } \\
\text { atmosphere }\end{array}$ & 7 & 2 & 73 & $\begin{array}{l}\text { Median size } \\
100 \% \text { over } \\
97.5 \% \%, \\
75 \% \%, \\
41 \% \text { ", } \\
12 \% \text { ", }\end{array}$ & $\begin{array}{l}1.6 \mu \\
0.2 \mu(-\%) \\
0.5 \mu(2.5 \% \\
1 \mu \quad(25 \% \\
2 \mu \quad(59 \% \\
5 \mu \quad(88 \%\end{array}$ & $\begin{array}{l}\text { less) } \\
\text {," } \\
\text {,") } \\
\text {, })\end{array}$ & 25 & 4 & 200 & 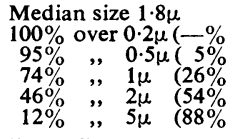 & $\begin{array}{l}\text { less) } \\
\text { ", } \\
\text {,") } \\
\text {,") }\end{array}$ \\
\hline $\begin{array}{l}\text { 5. Centre of } \\
\text { scutcher }\end{array}$ & 11 & 3 & - & & - & & 46 & 11 & - & - & \\
\hline 6. Fibre dressing .. & 14 & 4 & - & & - & & 34 & 5 & - & - & \\
\hline Overall averages $\ldots$ & 12 & 4 & - & & - & & 47 & 17 & - & - & \\
\hline Overall ranges & $7-21$ & $2-7$ & - & & - & & $18-113$ & $4-60$ & - & - & \\
\hline
\end{tabular}

The straws used during the tests were retted straw and green straw, with a moisture content of $10.5 \%$ and $15 \%$, and feed weight $/$ machine/ hr. of $717 \mathrm{lb}$. and $627 \mathrm{lb}$. respectively.

TABLE 4

GRAVIMETRIC AND DUST COUNT ESTIMATIONS AT FORDHAM FLAX FACTORY UNDER BLACK-OUT CONDITIONS

\begin{tabular}{|c|c|c|c|c|c|c|c|c|c|}
\hline \multirow[b]{2}{*}{$\begin{array}{l}\text { Sampling } \\
\text { Position }\end{array}$} & \multicolumn{5}{|c|}{$\begin{array}{l}\text { Plenum On } \\
\text { Series } 1\end{array}$} & \multicolumn{4}{|c|}{$\begin{array}{c}\text { Plenum On } \\
\text { Series } 2\end{array}$} \\
\hline & $\left|\begin{array}{c}\text { Total } \\
\text { Dust } \\
\left(\mathrm{mg} \cdot / \mathrm{m}^{3}\right)\end{array}\right|$ & $\mid \begin{array}{c}\text { Mineral } \\
\text { Dust } \\
\text { and } \\
\text { Organic } \\
\text { Ash } \\
\left(\mathrm{mg} . / \mathrm{m}^{3}\right)\end{array}$ & \begin{tabular}{|c|} 
Dust \\
Concen- \\
tration \\
(particles \\
per \\
c.cm.)
\end{tabular} & Size D & Distribution & $\mid \begin{array}{c}\text { Total } \\
\text { Dust } \\
\left(\mathrm{mg} \cdot / \mathrm{m}^{3}\right)\end{array}$ & $\left|\begin{array}{c}\text { Mineral } \\
\text { Dust } \\
\text { and } \\
\text { Organic } \\
\text { Ash } \\
\left(\mathrm{mg} . / \mathrm{m}^{3}\right)\end{array}\right|$ & \begin{tabular}{|c|} 
Dust \\
Concen- \\
tration \\
(particles \\
per \\
c.cm.)
\end{tabular} & Size Distribution \\
\hline 1. Feed table & 21 & 5 & 210 & $\begin{array}{l}\text { Median size } \\
99 \% \text { over } \\
88 \% \%, \\
71 \% \%, \\
44 \%, \\
8 \%,\end{array}$ & $\begin{array}{lll}1.75 \mu & & \\
0 \cdot 2 \mu & (1 \% & \text { less }) \\
0.5 \mu & (12 \% & ,,) \\
1 \% & (29 \% & ,,) \\
2 \cdot \mu & (56 \% & , ") \\
5 \mu & (92 \% & ,,)\end{array}$ & 25 & 5 & 256 & 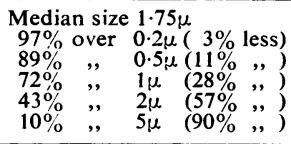 \\
\hline 3. Scutcher intake.. & 28 & 7 & - & & - & 28 & 5 & - & - \\
\hline $\begin{array}{l}\text { 4. General } \\
\text { atmosphere }\end{array}$ & 35 & 5 & 266 & $\begin{array}{l}\text { Median size } \\
98 \% \text { over } \\
86 \% \%, \\
69 \% \% \\
45 \%, ", \\
15 \%, ", \\
\end{array}$ & $\begin{array}{lll}1 \cdot 75 \mu & \\
0 \cdot 2 \mu & (2 \% & \text { less }) \\
0 \cdot 5 \mu . & (14 \% & , ") \\
1 \mu & (31 \% & , \\
2 \mu & (55 \% & ,,) \\
5 \mu & (85 \% & , \\
\end{array}$ & $\begin{array}{l}34 \\
\cdots\end{array}$ & 5 & 283 & 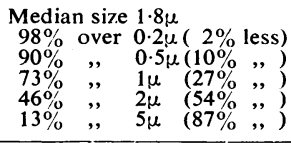 \\
\hline $\begin{array}{l}\text { 5. Centre of } \\
\text { scutcher }\end{array}$ & 106 & 11 & 一 & & - & 110 & 11 & - & - \\
\hline 6. Fibre dressing ... & 92 & 14 & - & & - & 88 & 11 & 一 & - \\
\hline Overall averages $\quad$. & 56 & 8 & 一 & & - & 57 & 7 & - & - \\
\hline Overall ranges & $21-106$ & $5-14$ & - & & - & $25-110$ & $5-11$ & - & - \\
\hline
\end{tabular}

The straw used during the test was green straw, with a moisture content of $13.9 \%$, and feed weight/machine/hr. of $595 \mathrm{lb}$.

trations of $7 \mathrm{mg} . / \mathrm{m}^{3}(0 \cdot 2 \mathrm{mg}$. $/ \mathrm{cu} . \mathrm{ft}$. $)$ in the general atmosphere of the scutching room and $18 \mathrm{mg} . / \mathrm{m}^{3}$ $(0.5 \mathrm{mg}$. $/ \mathrm{cu}$. ft. $)$ at the feeding tables, intakes and centres of scutchers, and fibre dressing ends of the machines as the provisional upper limits which could be permitted. 
Gravimetric Dust Surveys at Howden, Devizes, and Pluckley Flax Factories

Great efforts were made to cut down the air-borne dust concentrations in all the 17 flax factories, and to test the progress achieved further surveys were made in the scutching rooms of the Howden, Devizes, and Pluckley factories. Those at Howden and Devizes were extended surveys in which gravimetric samples were taken at all the six standard sampling positions during both day and night shifts, over a period of a fortnight.

Howden Flax Factory. - At the Howden standard factory, owing to shortage of maintenance staff, the plant and workroom had received only a partial cleaning and overhaul before the tests, 13 of which were carried out under normal working conditions in daytime and 10 during black-out. The first 18 tests were carried out with green straw being scutched and the remaining five with anaerobically retted straw. Tests were almost all of an hour's duration at times chosen to give an unbroken period of test. During most of the fortnight the weather was cold and dry and the humidity in the scutching room low. The plenum system of ventilation and the heating system were in operation throughout the tests. Variable winds affected the amount of day time draughts from the beet elevator openings and from the doors and windows. The results obtained are represented graphically in Fig. 3. They were disappointing in that the provisional standards were attained in only one of the 23 tests. It will be seen from Fig. 3 that the largest amounts of dust in the working atmosphere, in decreasing order, were usually found at (a) the centre of the scutcher, (b) the fibre dressing end of the machine, and (c) the scutcher intake, the general atmosphere position and the feeding table. In Table 5 a comparison is made of the dust conditions at the different points. The number of tests made with retted straw being smaller than with green straw, the variation in working conditions was correspondingly less, though throughout the two days when retted straw was being scutched the dust at all points appeared to be finer and was more

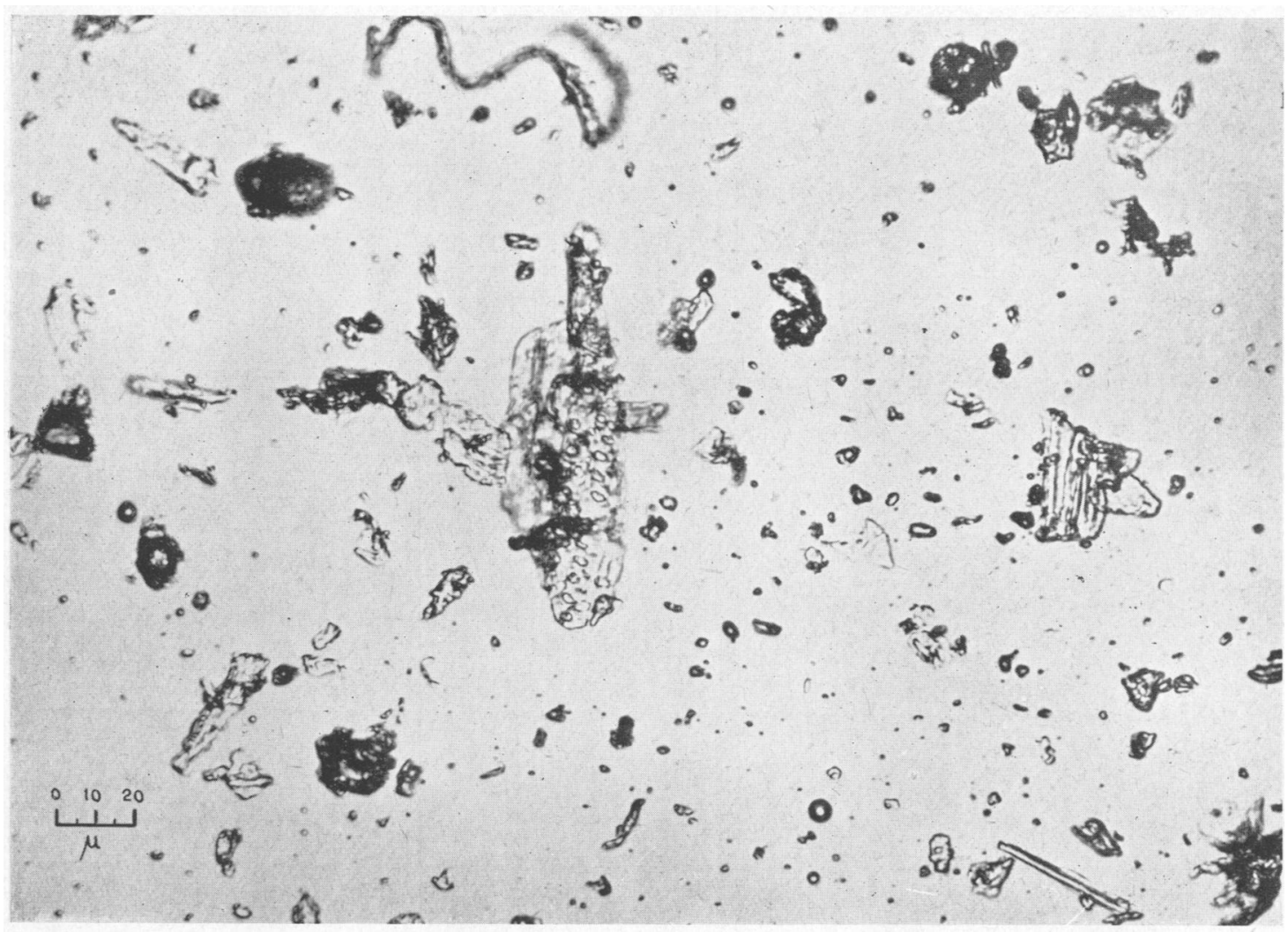

FIG. 2.-Photomicrograph $(\times 447)$ of thermal precipitator sample of air-borne flax scutching dust in the general atmosphere of the flax scutching room at West Newton factory under black-out conditions. 


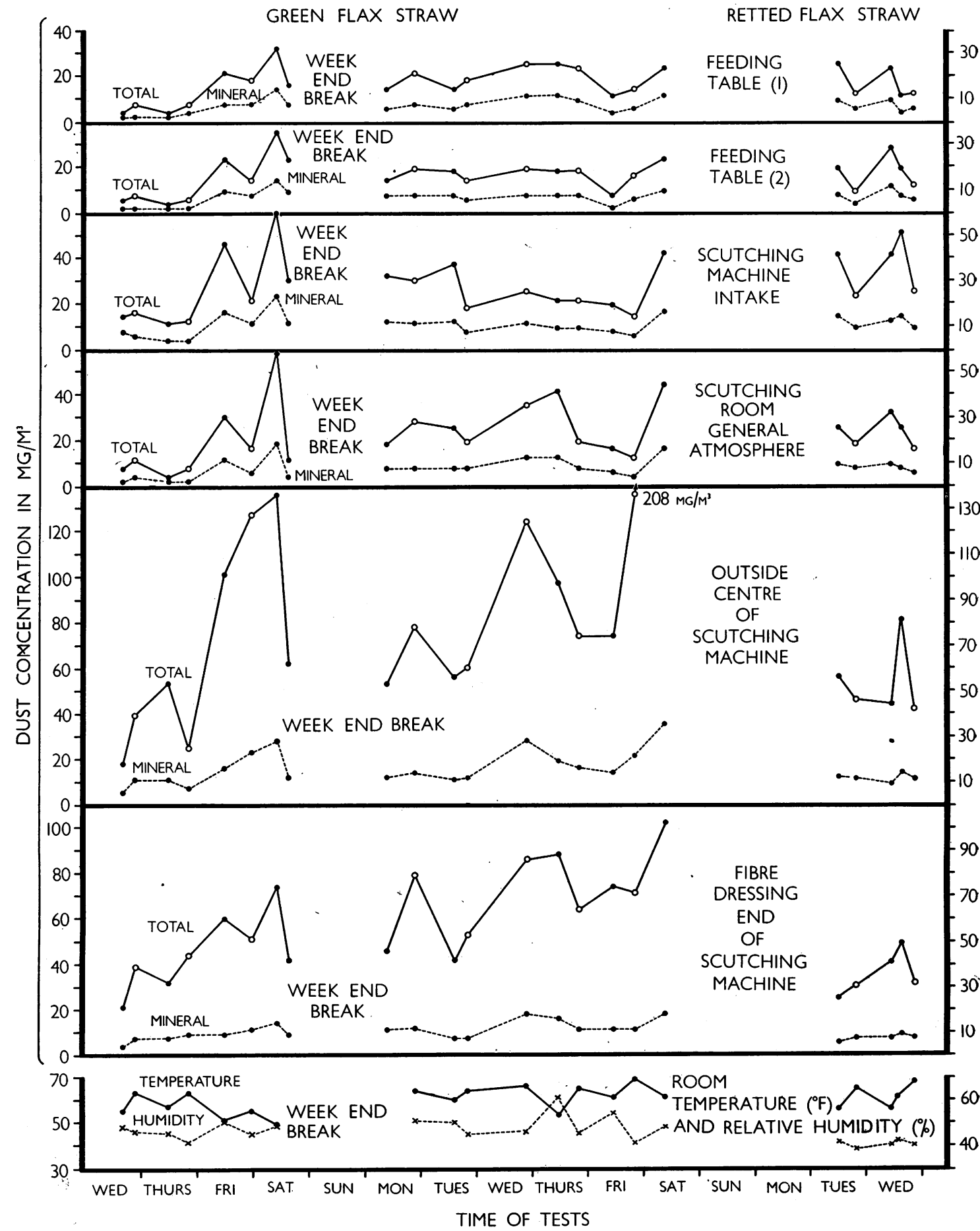

Fig. 3.-Graph of results of gravimetric dust survey ät Howden factory. 
TABLE 5

COMPARISON OF GRAVIMETRIC DUST ESTIMATIONS AT POINTS IN THE SCUTCHING ROOM AT HOWDEN FACTORY

\begin{tabular}{|c|c|c|c|c|c|c|c|c|c|c|}
\hline \multirow{3}{*}{ Sampling Position } & \multicolumn{5}{|c|}{ Green Straw } & \multicolumn{5}{|c|}{ Retted Straw } \\
\hline & \multirow[t]{2}{*}{$\begin{array}{l}\text { No. of } \\
\text { Tests }\end{array}$} & \multirow{2}{*}{$\begin{array}{l}\text { Failure } \\
\text { to } \\
\text { Attain } \\
\text { Standard }\end{array}$} & \multicolumn{2}{|c|}{$\begin{array}{c}\text { Average Dust } \\
\text { Content of } \\
\text { Air }\left(\mathrm{mg} \cdot / \mathrm{m}^{3}\right)\end{array}$} & \multirow{2}{*}{\begin{tabular}{|l|}
$\begin{array}{c}\text { Range } \\
\left(\dot{m} g . / \mathrm{m}^{3}\right)\end{array}$ \\
Total
\end{tabular}} & \multirow[t]{2}{*}{$\begin{array}{c}\text { No. of } \\
\text { Tests }\end{array}$} & \multirow{2}{*}{$\begin{array}{c}\text { Failure } \\
\text { to } \\
\text { Attain } \\
\text { Standard }\end{array}$} & \multicolumn{2}{|c|}{$\begin{array}{l}\text { Average Dust } \\
\text { Content of } \\
\text { Air }\left(\mathrm{mg} . / \mathrm{m}^{3}\right)\end{array}$} & \multirow{2}{*}{$\frac{\text { Rainge }}{\left(\mathrm{mg} \cdot / \mathrm{m}^{3}\right)}$} \\
\hline & & & Total & $\overline{\text { Mineral }}$ & & & & Total & Mineral & \\
\hline $\begin{array}{l}\text { 1. Feed table, end } \\
\text { 2. Feed table, mid-way } \\
\text { 3. Scutcher intake } \\
\text { 4. General atmosphere } \\
\text { 5. Centre of scutcher.. } \\
\text { 6. Fibre dressing }\end{array}$ & $\begin{array}{l}18 \\
18 \\
18 \\
18 \\
18 \\
18\end{array}$ & $\begin{array}{r}7 \\
6 \\
12 \\
15 \\
17 \\
18\end{array}$ & $\begin{array}{l}16 \\
16 \\
26 \\
22 \\
84 \\
59\end{array}$ & $\begin{array}{r}6 \\
6 \\
10 \\
7 \\
17 \\
11\end{array}$ & $\begin{array}{r}3-32 \\
3-35 \\
11-60 \\
3-58 \\
18-208 \\
21-102\end{array}$ & $\begin{array}{l}5 \\
5 \\
5 \\
5 \\
5 \\
5\end{array}$ & $\begin{array}{l}2 \\
3 \\
5 \\
5 \\
5 \\
5\end{array}$ & $\begin{array}{l}17 \\
18 \\
36 \\
23 \\
54 \\
35\end{array}$ & $\begin{array}{r}6 \\
7 \\
12 \\
7 \\
11 \\
7\end{array}$ & $\begin{array}{r}11-25 \\
9-28 \\
23-51 \\
16-32 \\
42-81 \\
25-49\end{array}$ \\
\hline Overall averages $\ldots$ & - & - & 37 & 9 & - & - & - & 30 & 8 & - \\
\hline Overall ranges & - & - & - & - & $3-208$ & - & - & - & - & $9-81$ \\
\hline
\end{tabular}

irritating to breathe than the dust from green straw. In general the amount of mineral matter, including ash of organic material, in the dusts from both green and retted straw decreased progressively from $35 \%$ to $40 \%$ at the feeding table to $15 \%$ to $20 \%$ at the fibre dressing end of the scutching machine.

The amount of dust liberated at the various sampling positions varied noticeably with the conditioning and mode of handling of the flax straw. The worst conditions were around the centre of the scutcher at the change-over point where occasional blockages in the exhaust system and leakages (facilitated by the action of the rotating beater blades which set up static pressures in the turbine casing) caused heavy local dust concentrations.

Devizes Flax Factory.-In view of the disappointing results at Howden it was decided to carry out further trials at the Devizes factory which had a good record for cleanliness and in which, since the original trial, the breaking roller portions of the scutching turbines had been converted to downdraught dust extraction. The aim of the trials was to see if the provisional dust standards could be attained under normal working conditions over a week with the plenum ventilation system in operation. Separate tests were done before and after the monthly clean up. In both series dusty green straw of poor quality was being scutched and there was no blackout at night. Test conditions were substantially the same except that relative humidities were higher on account of mild wet weather in the second series before the clean-up. The results, which are recorded graphically in Fig. 4, were again disappointing and exceeded the provisional standards in almost every test. A comparison of the average figures at the various points in the scutching room is given separately in Table 6 for both series of tests.

The same observations and conclusions applied for both tests. As was to be expected the proportion of mineral dust, including ash of organic matter, was highest at the feeding tables, the figures being similar to those at Howden. No dust was observed to rise from the turbine scutcher breaking rollers which had been converted to separate downdraught dust extraction. It seemed that even in a mill where maintenance was of a high order and down-draught extraction to the breaking rollers had been installed, it was not possible to attain the provisional standards laid down. In view of the results obtained in the original tests at Devizes the failure to achieve these was attributed to the poor and dusty quality of the straw; and since in the later trials the largest amount of dust was again emitted at the change-over sections of the turbines it appeared that there was little hope of any modification of the up-draught extraction system on the turbines, or any reasonable system of maintenance, giving conditions which would allow the provisional dustiness standards to be met. It became apparent that owing to inherent difficulties in design the upward extraction system was failing to maintain a suction in the scutcher turbine hoods and also that the hoods formed a tunnel in which dust collected and which could only be cleaned out with difficulty owing to its inaccessibility.

Pluckley Flax Factory.-The final series of dust measurements made in scutching rooms were at the Pluckley mill, one of the older standard factories operating two scutching machines, and here a trial covering four shifts was carried out after the down- 


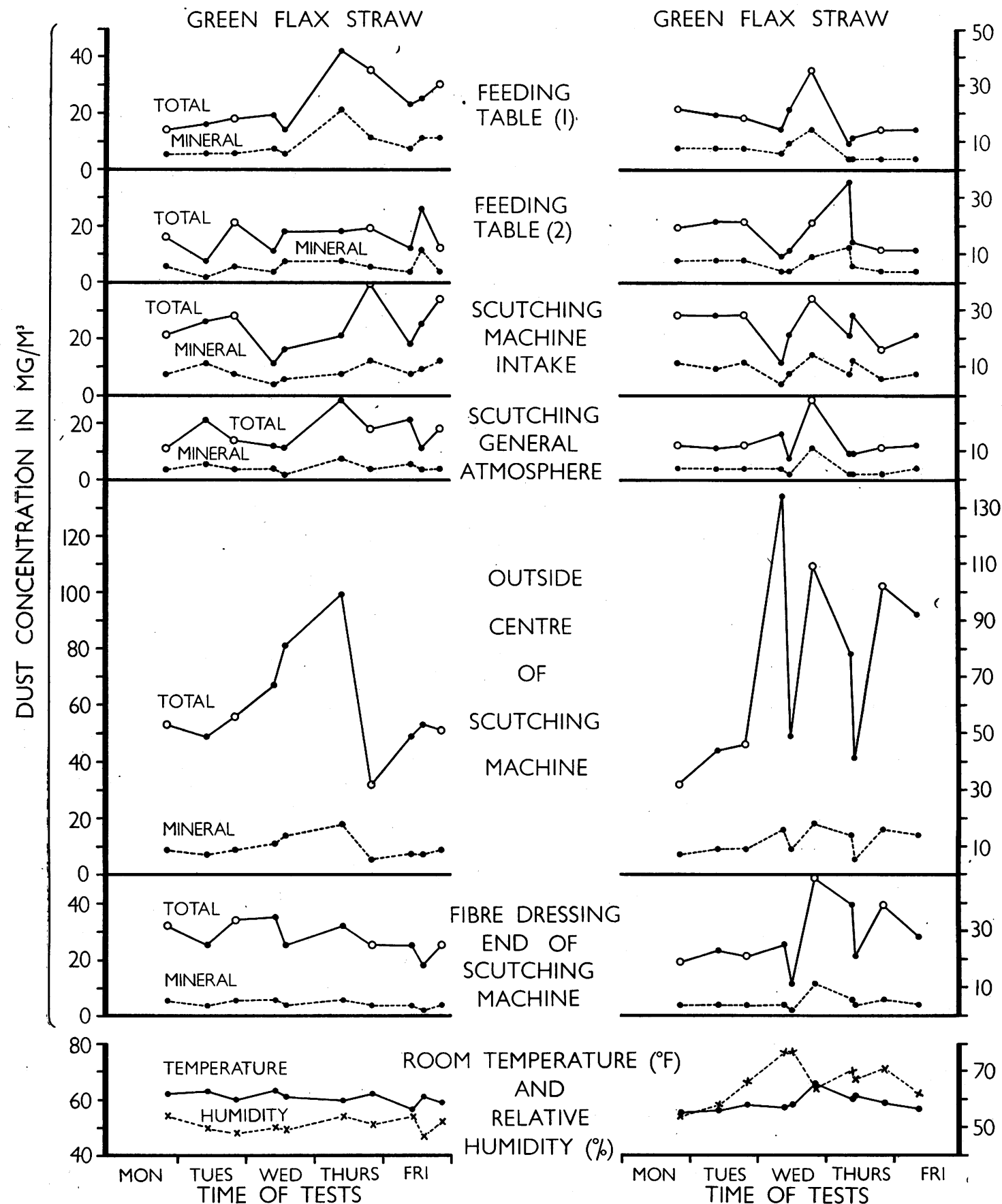

(STARTING IMMEDIATELY AFTER MONTHLY CLEAN UP) (STARTING ONE WEEK BEFORE MONTHLY CLEAN UP)

Fig. 4.-Graph of results of gravimetric dust survey at Devizes factory. 
TABLE 6

GRAVIMETRIC DUST ESTIMATIONS IN THE DEVIZES SCUTCHING ROOM FOR A WEEK BEFORE AND AFTER MONTHLY CLEAN-UP OF MACHINERY

\begin{tabular}{|c|c|c|c|c|c|c|c|c|c|}
\hline \multirow{4}{*}{\multicolumn{2}{|c|}{ Sampling Position }} & \multicolumn{8}{|c|}{ Green Straw } \\
\hline & & \multicolumn{4}{|c|}{ Average* $\begin{array}{c}\text { Dust Content of Air } \\
\left(\mathrm{mg} . / \mathrm{m}^{3}\right)\end{array}$} & \multicolumn{4}{|c|}{$\begin{array}{c}\text { Range } \\
\left(\mathrm{mg} . / \mathrm{m}^{3}\right)\end{array}$} \\
\hline & & \multicolumn{2}{|c|}{ Total } & \multicolumn{2}{|c|}{ Mineral } & \multicolumn{2}{|c|}{ Total } & \multicolumn{2}{|c|}{ Mineral } \\
\hline & & $\begin{array}{c}\text { Before } \\
\text { Cleaning }\end{array}$ & $\begin{array}{c}\text { After } \\
\text { Cleaning }\end{array}$ & $\begin{array}{c}\text { Before } \\
\text { Cleaning }\end{array}$ & $\begin{array}{c}\text { After } \\
\text { Cleaning }\end{array}$ & $\begin{array}{l}\text { Before } \\
\text { Cleaning }\end{array}$ & $\begin{array}{c}\text { After } \\
\text { Cleaning }\end{array}$ & $\begin{array}{l}\text { Before } \\
\text { Cleaning }\end{array}$ & $\begin{array}{l}\text { After } \\
\text { Cleaning }\end{array}$ \\
\hline $\begin{array}{l}\text { 1. Feed table, end .. } \\
\text { 2. Feed table, mid-way } \\
\text { 3. Scutcher intake .. } \\
\text { 4. General atmosphere } \\
\text { 5. Centre of scutcher } \\
\text { 6. Fibre dressing } \quad .\end{array}$ & $\begin{array}{l}\ldots \\
\cdots \\
\cdots \\
\cdots \\
\cdots\end{array}$ & $\begin{array}{l}18 \\
17 \\
24 \\
13 \\
73 \\
27\end{array}$ & $\begin{array}{l}24 \\
16 \\
24 \\
17 \\
60 \\
27\end{array}$ & $\begin{array}{r}6 \\
6 \\
9 \\
3 \\
12 \\
5\end{array}$ & $\begin{array}{r}9 \\
5 \\
8 \\
4 \\
10 \\
4\end{array}$ & $\begin{array}{c}9-35 \\
9-35 \\
11-34 \\
7-28 \\
32-134 \\
11-49\end{array}$ & $\begin{array}{r}14-42 \\
7-26 \\
11-39 \\
11-28 \\
32-99 \\
18-35\end{array}$ & $\begin{array}{l}3-14 \\
3-12 \\
3-14 \\
2-11 \\
7-18 \\
2-11\end{array}$ & $\begin{array}{l}5-21 \\
2-11 \\
3-12 \\
2-7 \\
5-18 \\
2-5\end{array}$ \\
\hline Overall averages $\ldots$ & .. & 29 & 28 & 7 & 7 & - & - & - & - \\
\hline Overall ranges & . & - & - & - & - & $7-134$ & $7-99$ & $2-18$ & $2-21$ \\
\hline
\end{tabular}

draught dust extraction system had been fitted both to the breaking rollers and to the scutching turbines themselves. Tests were made during the scutching of both green and tank retted straw and under both day and night conditions. As in previous tests, samples were taken over a period of about an hour and were begun after the scutching machines had run continuously for at least half an hour. Owing to the cold weather all outer doors were kept shut during both day and night tests. Ventilation openings in the walls were also closed and the fans re-circulated warmed air drawn from the room. The main sources of air replacing that withdrawn by the dust extraction system appeared to be the flax beet elevator openings and a nearby entrance to the adjacent de-seeding room, and there was a noticeable movement of air past the feeding tables towards the scutching machines.

The results of the tests are recorded in Table 7, and it will be seen that with the one exception of the green flax straw day time test the provisional dustiness limits of $7 \mathrm{mg}$. $/ \mathrm{m}^{3}$ in the general atmosphere and $18 \mathrm{mg} . / \mathrm{m}^{3}$ along the scutching machines were not exceeded. The down-draught dust extraction system worked satisfactorily, and on no occasion was dust observed rising from the machines, including the breaking rollers. In general the amount of dust was greatest at the feeding table, with smaller and uniform amounts at the centre and fibre dressing end of the machine and in the general atmosphere. The amount of mineral matter in the dust was also highest at the feeding table. Throughout the tests visual observation showed the general atmosphere of the scutching room to be reasonably good.

The results of these tests were very encouraging. With down-draught extraction with adequate fan power on both the breaking rollers and scutching turbines, together with careful plant maintenance and cleaning, the provisional dustiness standards were attained. In the three successful tests out of the four, the dust emitted at the centre change-over of the scutcher turbine was of the order of one tenth of that in the Devizes trial where up-draught extraction was in force, and it seemed that the down-draught system had overcome to a large extent the effect of static pressure in the turbine casing. Tests on the explosive properties of flax dust showed that it was readily ignitable but only by a source of heat of large size and high temperature (such as an electric arc) or one of long duration (such as the flame of a Bunsen burner). This result was encouraging also, as it largely removed the fear that with down-draught extraction an accumulation of dust in tunnels under scutching machines might introduce a serious explosive risk.

The Directorate of Home Flax Production therefore decided to change up-draught extraction on the scutcher turbines to some suitable type of downdraught extraction at all mills as and when opportunity arose and local structural conditions permitted. Visual observation suggests that the subsequent history of the industry has been one of steady improvement arising from this decision, from the introduction of new designs of more nearly totally enclosed and exhausted machines, and from 
TABLE 7

GRAVIMETRIC DUST ESTIMATIONS AT PLUCKLEY FLAX FACTORY

\begin{tabular}{|c|c|c|c|c|c|c|c|c|c|c|}
\hline \multirow{3}{*}{\multicolumn{3}{|c|}{ Sampling Position }} & \multicolumn{4}{|c|}{ Green Straw } & \multicolumn{4}{|c|}{ Tank-Retted Straw } \\
\hline & & & \multicolumn{2}{|c|}{ Daytime } & \multicolumn{2}{|c|}{ Night-time } & \multicolumn{2}{|c|}{ Daytime } & \multicolumn{2}{|c|}{ Night-time } \\
\hline & & & $\begin{array}{c}\text { Total } \\
\text { Dust } \\
\left(\mathrm{mg} . / \mathrm{m}^{3}\right)\end{array}$ & $\begin{array}{c}\text { Mineral } \\
\text { Dust and } \\
\text { Organic } \\
\text { Ash } \\
\left(\mathrm{mg} . / \mathrm{m}^{3}\right) \\
\end{array}$ & $\begin{array}{c}\text { Total } \\
\text { Dust } \\
\left(\mathrm{mg} . / \mathrm{m}^{3}\right)\end{array}$ & $\begin{array}{c}\text { Mineral } \\
\text { Dust and } \\
\text { Organic } \\
\text { Ash } \\
\left(\mathrm{mg} . / \mathrm{m}^{3}\right)\end{array}$ & $\begin{array}{c}\text { Total } \\
\text { Dust } \\
\left.\text { (mg. } / \mathrm{m}^{3}\right)\end{array}$ & $\begin{array}{c}\text { Mineral } \\
\text { Dust and } \\
\text { Organic } \\
\text { Ash } \\
\left(\mathrm{mg} \cdot / \mathrm{m}^{3}\right)\end{array}$ & $\begin{array}{c}\text { Total } \\
\text { Dust } \\
\left(\mathrm{mg} . / \mathrm{m}^{3}\right)\end{array}$ & $\begin{array}{c}\text { Mineral } \\
\text { Dust and } \\
\text { Organic } \\
\text { Ash } \\
\left(\mathrm{mg} / \mathrm{m}^{3}\right)\end{array}$ \\
\hline $\begin{array}{l}\text { 1. Feed tal } \\
\text { 2. Feed ta } \\
\text { 3. Scutche } \\
\text { 4. General } \\
\text { 5. Centre } \\
\text { 6. Fibre d }\end{array}$ & $\begin{array}{l}\text { le, end ... } \\
\text { le, mid-way } \\
\text { intake . . } \\
\text { atmosphere } \\
\text { f scutcher } \\
\text { essing ... }\end{array}$ & $\begin{array}{l}\cdots \\
\cdots \\
\cdots \\
\cdots \\
\cdots\end{array}$ & $\begin{array}{l}21 \\
21 \\
21 \\
16 \\
16 \\
16\end{array}$ & $\begin{array}{l}7 \\
7 \\
7 \\
5 \\
3 \\
3\end{array}$ & $\begin{array}{r}16 \\
16 \\
11 \\
7 \\
5 \\
5\end{array}$ & $\begin{array}{l}5 \\
5 \\
3 \\
2 \\
2 \\
2\end{array}$ & $\begin{array}{r}- \\
11 \\
7 \\
7 \\
7 \\
7\end{array}$ & $\begin{array}{l}- \\
3 \\
3 \\
2 \\
2 \\
2\end{array}$ & $\begin{array}{r}- \\
11 \\
5 \\
3 \\
3 \\
3\end{array}$ & $\begin{array}{l}-3 \\
2 \\
1 \\
1 \\
1\end{array}$ \\
\hline Averages & . & . & 18 & 5 & 10 & 3 & 8 & 2 & 5 & 2 \\
\hline Ranges & $\ldots \quad \ldots$ & $\cdots$ & $16-21$ & $3-7$ & $5-16$ & $2-5$ & $7-11$ & $2-3$ & 3. 11 & 13 \\
\hline \multicolumn{2}{|c|}{ Room temperature .. } & $\cdots$ & \multicolumn{2}{|c|}{$47^{\circ} \mathrm{F}$} & \multicolumn{2}{|c|}{$45^{\circ} \mathrm{F}$} & \multicolumn{2}{|c|}{$47^{\circ} \mathrm{F}$} & \multicolumn{2}{|c|}{$45^{\circ} \mathrm{F}$} \\
\hline Relative hı & midity $\ldots$ & . & \multicolumn{2}{|c|}{$59 \%$} & \multicolumn{2}{|c|}{-} & \multicolumn{2}{|c|}{ - } & \multicolumn{2}{|c|}{ 一 } \\
\hline \multicolumn{3}{|c|}{ Feed weight/machine/hour } & \multicolumn{4}{|c|}{$900 \mathrm{lb}}$. & \multicolumn{4}{|c|}{$1,000 \mathrm{lb}$} \\
\hline \multicolumn{3}{|c|}{ Overall averages } & \multicolumn{8}{|c|}{$11 \mathrm{mg} . / \mathrm{m}^{3}$ (total dust) and $3 \mathrm{mg} . / \mathrm{m}^{3}$ (mineral dust) } \\
\hline$\overline{\text { Overall ra }}$ & $\cdots$ & . & \multicolumn{8}{|c|}{$3-21 \mathrm{mg} . / \mathrm{m}^{3}$ (total dust) and $1-7 \mathrm{mg} . / \mathrm{m}^{3}$ (mineral dust) } \\
\hline
\end{tabular}

the improvements in general and exhaust ventilation and in plant maintenance and cleaning made possible by the return of peace time conditions and improvements in the labour supply. It is not the purpose of this paper to record these and many other subsequent improvements. It is only desired to place on record here the air-borne dust conditions which existed in the flax scutching industry in the early years of world war II.

\section{Dust Estimations in Tow Rooms}

A few gravimetric dust estimations were made under normal day time conditions in the separate tow rooms situated underneath the scutching rooms. The preparing, straightening out, and cleaning of the tow is done on machines, such as tow rollers and beaters (fitted with a set of multiple, fluted rollers for breaking scutching rug, and with intermediate beater blades), tow scutchers (machines specially designed for scutching rug into tow), high speed tow shakers (machines with rapidly vibrating steel pins for shaking out tow after treatment by the previous machines), slow speed shakers (machines for shaking out the shives), and roughing-out machines (for roughly separating the seed from the chaff, short straw, weeds etc., produced during the de-seeding process). Dust samples were taken over a period of an hour at breathing level at three factories, Fordham, Howden, and Pluckley, usually at or near positions where the dust clouds coming from the machines appeared visually to be worst, and were made after the machines had been running for at least half an hour. The air-borne dust concentrations (Table 8) were similar to those found in scutching rooms with up-draught local exhaust ventilation and were in excess of the provisional standards of dustiness for scutching rooms. The conclusion drawn from the tests was the need for the tow roller and beater machines to be enclosed and exhausted and for other dust producing sources, such as seed cleaning plant, to be similarly dealt with.

\section{Chemical and Spectrographic Analyses of Flax Dust}

From a study of the literature it appears that little work has been done on the possible hazard of silicosis from flax dust. Glibert (1902) quotes chemical analyses of single samples of natural and retted flax straw and fibre due to Wolf ("Etude sur les engrais") and of flax straw ash made by Professor Hodges, of Belfast, from which it appears that the free silica contents of the straw and fibre varied between about 0.1 and $0.5 \%$. The only other published analyses (of flax seed and straw) 
TABLE 8

GRAVIMETRIC DUST ESTIMATIONS MADE IN THE TOW ROOMS AT FORDHAM, HOWDEN, AND PLUCKLEY FLAX FACTORIES

\begin{tabular}{|c|c|c|c|c|c|c|c|c|}
\hline \multirow{2}{*}{\multicolumn{3}{|c|}{ Sampling Position }} & \multicolumn{2}{|c|}{ Fordham } & \multicolumn{2}{|c|}{ Howden } & \multicolumn{2}{|c|}{ Pluckley } \\
\hline & & & $\begin{array}{c}\text { Total } \\
\text { Dust } \\
\text { (mg. } / \mathrm{m}^{3} \text { ) }\end{array}$ & $\begin{array}{c}\text { Mineral } \\
\text { Dust and } \\
\text { Organic } \\
\text { Ash } \\
\left(\mathrm{mg} \cdot / \mathrm{m}^{3}\right)\end{array}$ & $\begin{array}{c}\text { Total } \\
\text { Dust } \\
\text { (mg. } / \mathrm{m}^{3} \text { ) }\end{array}$ & $\begin{array}{c}\text { Mineral } \\
\text { Dust and } \\
\text { Organic } \\
\text { Ash } \\
\left(\mathrm{mg} \cdot / \mathrm{m}^{3}\right)\end{array}$ & $\underset{\left(\mathrm{mg} \cdot / \mathrm{m}^{3}\right)}{\text { Total }}$ & $\begin{array}{c}\text { Mineral } \\
\text { Dust and } \\
\text { Organic } \\
\text { Ash } \\
\left.\text { (mg. } / \mathrm{m}^{3}\right)\end{array}$ \\
\hline \multicolumn{3}{|c|}{$\begin{array}{l}\text { Four feet from sack fitted to cyclone outlet } \\
\text { hopper of roughing-out machine }\end{array}$} & - & - & - & 一 & 49 & 32 \\
\hline \multicolumn{3}{|c|}{$\begin{array}{l}\text { At feeding table to intake of tow roller and } \\
\text { beater machine }\end{array}$} & 56 & 11 & 30 & 9 & - & - \\
\hline \multicolumn{3}{|c|}{ Mid-way along tow roller and beater machine } & - & - & - & - & 35 & 14 \\
\hline \multicolumn{3}{|c|}{$\begin{array}{l}\text { At end of tow roller and beater machine near } \\
\text { operator feeding high speed shaker }\end{array}$} & 28 & 5 & 11 & 3 & - & $\longrightarrow$ \\
\hline \multicolumn{3}{|c|}{$\begin{array}{l}\text { General atmosphere near centre of tow room } \\
\text { away from machines }\end{array}$} & 18 & 3 & 11 & 3 & - & - \\
\hline Room temperature & . & . & \multicolumn{2}{|c|}{ - } & \multicolumn{2}{|c|}{$56^{\circ} \mathrm{F}$} & \multicolumn{2}{|c|}{$45^{\circ} \mathrm{F}$} \\
\hline Relative humidity & $\cdots$ & $\cdots$ & \multicolumn{2}{|c|}{ High } & \multicolumn{2}{|c|}{$52 \%$} & \multicolumn{2}{|c|}{$59 \%$} \\
\hline Type of rug $\quad$. & $\cdots$ & $\cdots$ & \multicolumn{2}{|c|}{ Retted } & \multicolumn{2}{|c|}{ Green } & \multicolumn{2}{|c|}{ Green } \\
\hline Overall averages & $\cdots$ & $\cdots$ & \multicolumn{6}{|c|}{$30 \mathrm{mg} \cdot / \mathrm{m}^{3}$ (total dust) and $10 \mathrm{mg} \cdot / \mathrm{m}^{3}$ (mineral dust) } \\
\hline Overall ranges .. & . & . & \multicolumn{6}{|c|}{$11-56 \mathrm{mg} . / \mathrm{m}^{3}$ (total dust) and $3-32 \mathrm{mg} \cdot / \mathrm{m}^{3}$ (mineral dust) } \\
\hline
\end{tabular}

which can be traced-those of Mach and Herrmann (1934), McHargue (1923), and Bertrand and Benzon (1929) on a limited number of samples-make no reference to silica contents but show potassium, phosphorus, magnesium, calcium, sulphur, iron, manganese, and zinc as present in amounts decreasing, in the order listed, from $0.63 \%$ to trace values. Chemical analyses for silica content and spectrographic analyses of mineral ash were therefore made on samples of flax dust.

The samples necessarily contained a considerable amount of coarse fibrous material, which was removed by sieving through a B.S. sieve of mesh 300 (nominal size of square apertures $53 \mu$ ). The fine dust passing this sieve was examined chemically with the results shown in Table 9. The free silica determinations were made by the standard fluoboric acid method (Line and Aradine, 1937). The results of the spectrographic examination of the mineral ash derived from the samples are recorded in Table 10.

It is of considerable interest that the dust from the scutching of green flax contained $4.4 \%$ free silica, while that from retted flax contained between $6.5 \%$ and $8.2 \%$ according to whether the retting had been anaerobic or aerobic. Highest of all in free silica was the dust from the de-seeding of green straw, at $12.7 \%$. This was to be expected in this early part of the scutching process because of the field dust and soil adhering to the straw and root ends (which are sliced off at this stage), since flax is a crop which is mostly pulled, not cut. While the free silica percentages are not high, they are by no means negligible, though it is realized that the dust samples analysed were not air-borne when sampled and so were coarser and not necessarily of exactly the same composition as the true air-borne dusts. Dusts containing the free silica percentages quoted could only cause serious effects after a long term of years spent in the industry, but taken in conjunction with the fairly high dust concentrations which have been shown to exist in this industry we conclude that a medical follow-up of long service workers would be justified. It cannot yet be said that the flax scutching process is free from a silicosis risk.

Taking into account all these considerations, the health records of the workers already described, the probability under peace time conditions of a relatively smaller labour turnover, and reviewing the whole of the dust estimations recorded in the paper, we are of the opinion that air-borne dust from all flax scutching processes should be controlled so as 
TABLE 9

CHEMICAL ANALYSES FOR SILICA CONTENT OF VARIOUS FLAX DUSTS

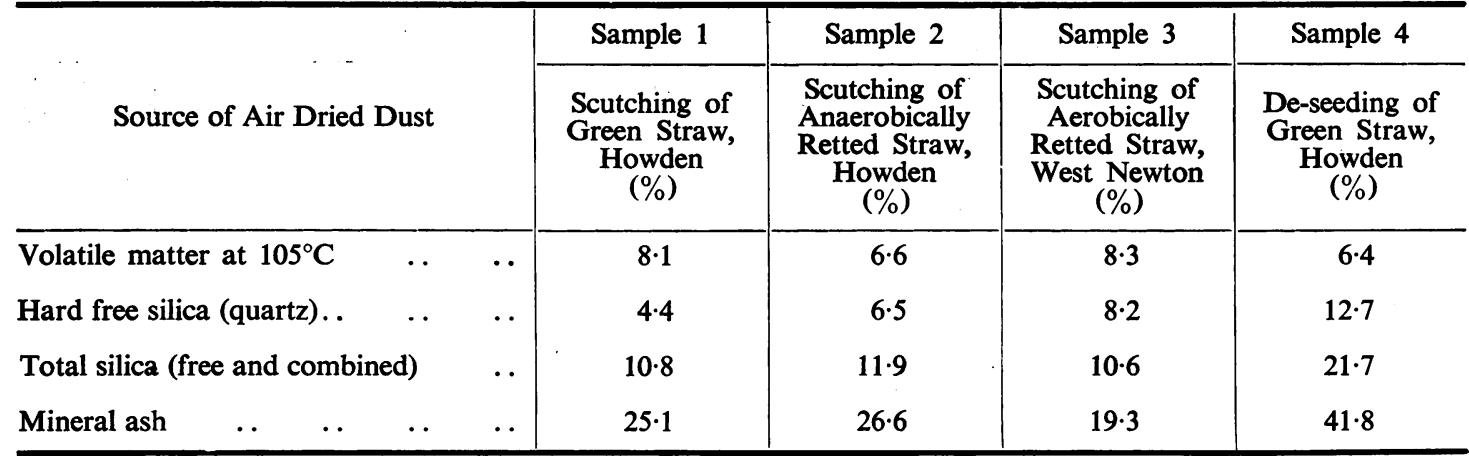

TABLE 10

SPECTROGRAPHIC EXAMINATION OF MINERAL ASH FROM FLAX DUSTS

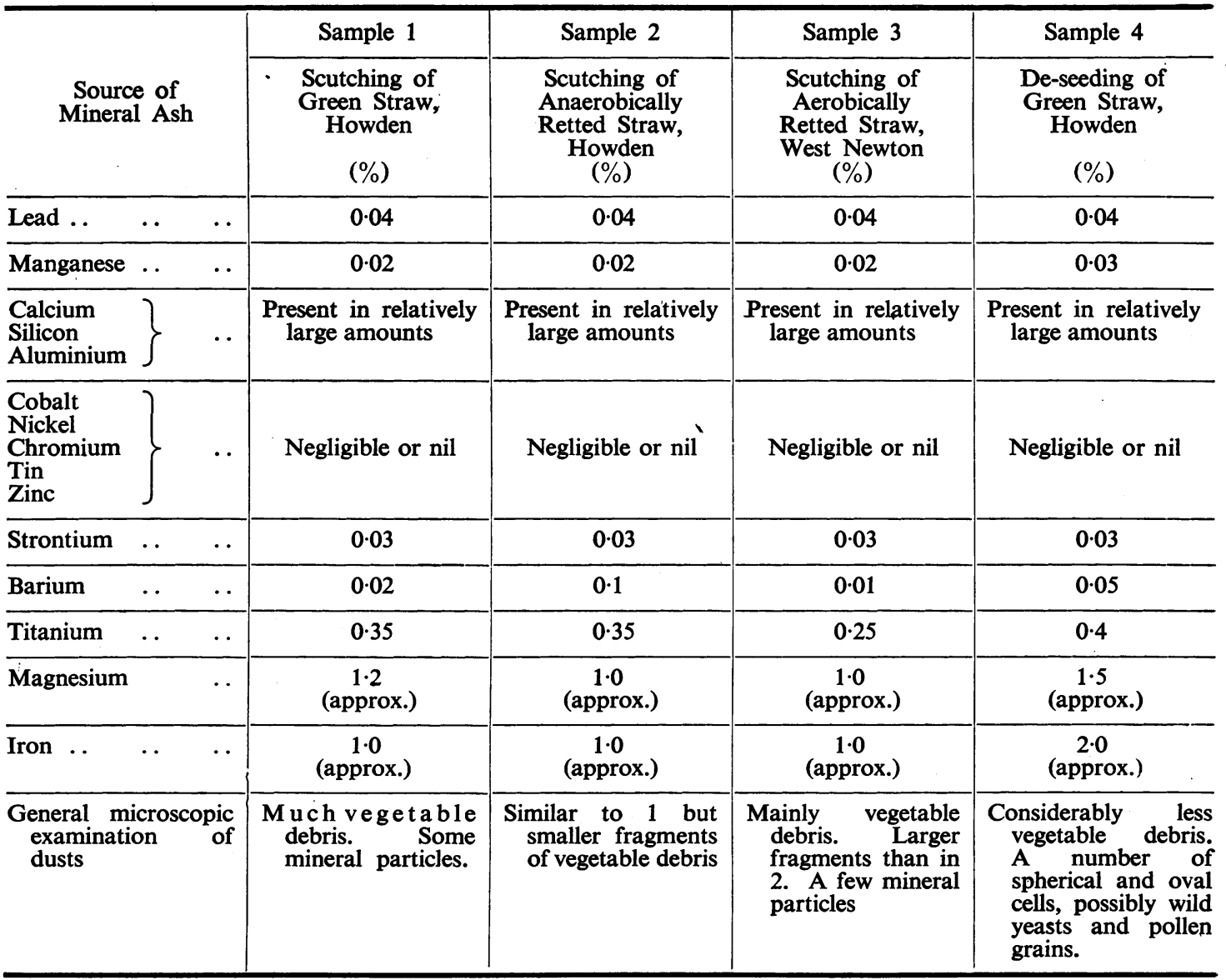

Samples 1 and 2 were taken from bag filters connected to the scutching machine; Sample 3 from an exhaust duct connected to a scutching machine; Sample 4 from bag filters connected to a de-seeding machine. 
not to exceed $10 \mathrm{mg}$./cu. metre and we suggest this figure as a maximum allowable concentration. In our experience this. amount would correspond approximately to a thermal precipitator dust count of about 100 particles per $\mathrm{c.cm}$.

\section{Summary}

The literature on flax dust health hazards is reviewed, and data are given on the dust and health conditions existing in British flax scutching factories between 1943 and 1945. Air-borne dust concentrations in the flax scutching rooms were initially high and were criticized by a Parliamentary Select Committee.

To assist in ascertaining the causes of these conditions and in remedying them, dust surveys were made in the scutching rooms of six of the factories. The surveys mainly comprised gravimetric estimations employing a sintered glass filtration method, which is described. Three hundred and seventeen results for six standard sampling positions in the scutching rooms are reported.

The overall average of the air-borne dust concentrations measured was $31 \mathrm{mg} . / \mathrm{m}^{3}$ with a range from 3 to $208 \mathrm{mg}$. $/ \mathrm{m}^{3}$.

The amount of mineral dust and ash of organic material in these gravimetric samples varied from between $35-40 \%$ of the total dust at the feed tables of the scutching machines to $15-20 \%$ at the fibre dressing end of the machines.

A few gravimetric determinations were also made of the air-borne dust in the tow rooms of three of the flax factories and results similar to those for the scutching rooms were obtained.

A limited number of thermal precipitator dust counts and size distribution estimations were made at the same time as the gravimetric estimations in the scutching rooms of four of the flax factories. The counts ranged between 42 and 283 particles per c.cm., with median particle sizes between 1.5 and $2 \cdot 6 \mu$.
Free silica was present in amounts ranging from $4.4 \%$ to $12 \cdot 7 \%$. It is considered that flax scutching presents a small but probable long term silicosis risk to the operatives. A maximum allowable concentration of $10 \mathrm{mg}$./cu. metre for air-borne flax scutching dust is proposed.

We are grateful to Major G. O. Searle, O.B.E., Superintendent of H.M. Norfolk Flax Establishment, for his interest and encouragement through all stages of the work. We wish to thank Mr. A. A. Russell and Dr. J. A. C. McClelland, both of the Government Laboratory, the first for valuable assistance in taking many of the gravimetric samples in the early stages of the work, the second for the spectrographic analyses of the mineral ash from flax dusts given in Table 10.

Finally we are indebted to H.M. Chief Inspector of Factories, to the Government Chemist, and to the Chief Scientist of the Ministry of Supply for permission to publish the results of our work.

\section{REFERENCES}

Allen, L. A. (1946). J. Soc. chem. Ind., Lond., (Trans.), 65365. Arlidge, J. T. (1892). "The Hygiene, Diseases and Mortality of Occupations". p. 373 . London.

Bargeron, L. (1930). "Flax and Linen Industry", in "Occupation and Health: Encyclopaedia of Hygiene, Pathology and Social Welfare." I.L.O., Geneva.

Barltrop, S. B. (1942). Proc. Instn. mech. Engrs., 148, 162.

Bertrand, G., and Benzon, B. (1929). Ann. Inst. Pasteur, 43, 386.

Collis, E. L.'(1915). Milroy Lectures. Publ. Hith., Lond., 28, 261.

Glibert, D. (1902). "Les Filatures de Lin." Ministère de 1 " Industrie, Bruxelles.

Grainger, F. (1949). J. Text. Inst., Manchr. (Proc.), 40, 918.

Grainger, F. (1949). J. Text. Inst., Manchr. (Proc.), 40, 918.
Greenhow, H. H. (1860). Third Report of the Medical Officer of the Privy Council. Appendix VI. p. 151. London.

Lanigan, G. W. (1950). Nature, Lond., 165, 516.

Line, W. R., and Aradine, P. W. (1937), Industr. Engng. Chem. (Anal. Ed.), 9, 60.

Mach, F., and Herrmann, R. (1934). Landw. Vers. Sta., 119, 1.

McHargue, J. S. (1923). J. agric. Res., 23, 395.

Ministry of Supply. (1944). "Glossary of Technical Terms used in Flax Cultivation and Processing."

Flax Cultivation and Processing."
Oldham, B. C. (1948). J. Jr. Instn. Engrs., 58, 133.

Oldham, B. C. (1948). J. Jr. Instn. Engrs., 58, 133 . C.md. 7287. H.M.S.O. London.

Peel, G. N. (1947). Industr. Chem., 23, 609.

Purdon, C. D. (1873). " "On the Mortality of Flax Workers."

Ramazzini, B. (1705). "A Treatise of the Diseases of Tradesmen", p. 175. London.

Select Committee on National Expenditure. (1943). "Home Flax Production." Session 1942-43 : Fifth Report. H.M.S.O. London.

Thackrah, C. T. (1832). “The Effects of Arts, Trades, and Professions, and of Civic States and Habits of Living on Health and Longevity". 2nd Edn. pp. 70-84 London.

Thiry, U. (1941). Arch. Mal. prof., 3, 129.

Turner, A. J. (1949). J. Text. Inst., Manchr. (Proc.), 40, 857. 


\section{A P P E N D I X}

\section{Gravimetric Method of Sampling}

Six gravimetric samples are collected simultaneously. The sintered glass filters, fixed at the desired sampling positions, are connected by long lengths of rubber pressure tubing to six flowmeters in a control box situated in a convenient central position. The flowmeters indicate the pressure difference developed across glass capillary tubes by the air pulled through the filters by a vacuum pump, and consist of vertical glass tubes, dipping into glass reservoirs containing water dyed with Kiton red and a drop or two of a wetting agent to prevent any sticking of the meniscus in the tubes. The dust filters are connected via the flowmeters to common brass headers and thence either to atmosphere, for adjusting flowmeter scale zeros, or to an electric rotary vacuum pump (Edward's). The flow of air through each filter is controlled by a needle valve in the flowmeter box and it has been usual to work at the maximum of the flowmeter scale, corresponding to 140 litres/hour, at which rate there is still a useful suction reserve to allow for adjustments. The flowmeters were calibrated against a standard wet gas meter. An average sampling test lasted about one to one and a half hours. The sintered glass filters used were Baird and Tatlock crucibles (Type Numbers $317 \mathrm{H} 3$ or $61 \mathrm{H} 3$ ) of disc diameter $30 \mathrm{~mm}$. and of porosity 3 (nominal porosity $25 \mu$ ). This porosity was chosen after preliminary gravimetric tests had been made of the filtrating efficiency of discs of varying porosity using very dense flax dust clouds at one of the standard factories. With a $25 \mu$ and an $11 \mu$ nominal porosity filter (each backed by a $7 \mu$ nominal porosity disc) sampling dust concentrations of 205 and $162 \mathrm{mg}$./cu. metre respectively, the dust penetrating the first discs (initially clean) to the $7 \mu$ discs was not weighable within the limit of sensitivity of the balance $( \pm 0.1 \mathrm{mg}$.) when 7.2 and $8.0 \mathrm{mg}$. of dust had been collected on the first discs. The $25 \mu$ nominal porosity (porosity 3 ) discs have a lower resistance to air flow than the others, so enabling quicker sampling rates to be achieved. At the chosen rate of 140 litres/hour the resistance of a clean filter averaged about $45 \mathrm{~mm} . \mathrm{Hg}$, which is about seven times that of a No. 1 Whatman filter paper of similar diameter. As a more accurate check on the efficiency of these $25 \mu$ porosity sintered glass filters working at 140 litres/hour against fine air-borne dust particles, thermal precipitator samples of dust both entering and leaving the filters were taken, using green flax dust in the general air of the Howden factory scutching room. Using special adapters to enable the air passing the filters to be sampled three separate tests were made. The first filter was tested for the later half of its $\mathbf{5 0}$ minute run so that the test might cover the later stages of filtration after it had collected some dust and was presumably in a more efficient state. The second and third filters were tested over the whole of an hour's run so that the initial stages of filtration when the filters might be expected to be least efficient were included. The second filter was a new one, while the third was a cleaned filter used on many previous occasions. The gravimetric dust concentrations of the dust clouds at the sampling point varied between 20 and $28 \mathrm{mg} / \mathrm{cu}$. metre. In the tests of the first and third filters the thermal precipitator dust concentrations entering the filter were 424 and 193 particles per c.cm. respectively, with median dust cloud sizes of $0.8 \mu(18 \%$ less than $0.2 \mu, 54 \%$ less than $1 \mu$, and $90 \%$ less than $5 \mu$ ), while for the new second filter the dust concentration was 292 particles per c.cm. of median size $0.4 \mu(25 \%$ less than $0 \cdot 2 \mu, 72 \%$ less than $1 \mu$ and $96 \%$ less than $5 \mu$ ). A careful microscope search, using both low and high power objectives, of the thermal precipitator samples of the air passing the filters failed to show any deposit of dust particles. The inference was that the $25 \mu$ nominal porosity sintered glass filters retained substantially $100 \%$ of particles down to $0 \cdot 2 \mu$ in diameter under our working conditions.

Before use the sintered glass filters were chemically cleaned and dried, conditioned overnight in a desiccator over anhydrous $\mathrm{CaCl}_{2}$, and weighed on a sensitive balance. They were then sealed with a cellophane wrapping held in place by a rubber band and packed in compartmented boxes ready for use. After sampling the filters were again wrapped in cellophane for transport back to the laboratory and were re-weighed after conditioning overnight as before. The filters were then ignited at between $450^{\circ} \mathrm{C}$ and $500^{\circ} \mathrm{C}$ to enable the mineral dust and organic ash content of the samples to be determined by further re-weighing after again conditioning overnight as before. 